\title{
Bacillus sp. PS35 Lipase-Immobilization on Styrene-Divinyl Benzene Resin and Application in Fatty Acid Methyl Ester Synthesis
}

\author{
Kanmani Palanisamy *, Kumaresan Kuppamuthu, Aravind Jeyaseelan \\ Department of Biotechnology, Kumaraguru College of Technology, Tamilnadu, India \\ ${ }^{*}$ Corresponding author: Palanisamy Kanmani, Biotechnology, Kumaraguru College of Technology, Tamilnadu, India. Tel: +91-4222669401, Fax: +91- \\ 4222669406, E-mail: kanmaniaravind@yahoo.com
}

Received: May 01, 2015; Revised: August 01, 2015; Accepted: August 23, 2015

\begin{abstract}
Background: Lipase is an enzyme with immense application potential. Ester synthesis by lipase catalysis in organic media is an area of key industrial relevance. Enzymatic preparations with traits that cater to the needs of this function are hence being intensely researched.

Objective: The objectives of the study were to immobilize the lipase from Bacillus sp. PS35 by cross-linking and adsorption onto styrene-divinyl benzene (Sty-Dvb) hydrophobic resin and to comparatively characterize the free and immobilized lipase preparations. The work also aimed to apply the immobilized lipase for catalysing the fatty acid methyl ester (FAME) synthesis from palm oil and optimize the process parameters for maximizing the yield.

Materials and Methods: In this study, the purified lipase from Bacillus sp. PS35 was immobilized by adsorption onto styrene-divinyl benzene hydrophobic resin with gluteraldehyde cross-linking.

Results: The immobilized enzyme showed better $\mathrm{pH}$ and temperature stabilities than the free lipase. Organic solvent stability was also enhanced, with the relative activity in the presence of methanol being shifted from $53 \%$ to $81 \%$, thereby facilitating the enzyme's application in fatty acid methyl ester synthesis. It exhibited remarkable storage stability over a 30 -day period and after 20 repetitive uses. Cross-linking also reduced enzyme leakage by $49 \%$. The immobilized lipase was then applied for biodiesel production from palm oil. Methanol and oil molar ratio of 5:1, three step methanol additions, and an incubation temperature of $50^{\circ} \mathrm{C}$ were established to be the ideal conditions favoring the transesterification reaction, resulting in $97 \%$ methyl ester yield.

Conclusions: These promising results offer scope for further investigation and process scale up, permitting the enzyme's commercial application in a practically feasible and economically agreeable manner.

Keywords: Bacillus sp. PS35; Biodiesel production; Cross-linking; Hydrophobic support; Lipase
\end{abstract}

\section{Background}

Lipases (triacylglycerol acylhydrolases EC.3.1.1.3) catalyse the hydrolysis of long-chain triacylglycerols by acting at the oil-water interface. They also catalyse the reverse reactions of esterification, transesterification and interesterification in non-aqueous environments. Formation of aggregate super substrates such as an emulsion, results in a drastic increase in lipase activity upon comparison to monomeric substrates. This is known as the phenomenon of interfacial activation (1). The lid that covers the active site might be displaced during interfacial activation, hence allowing access to the active site. When a hydrophobic surface such as an oil droplet is present, the lid gets displaced and the enzyme turns into an 'open' form. This permits the hydrophobic inner face and the hydrophobic residues that surround the active site to interact with the substrate (2).
The need for interfacial activation poses some practical constraints when immobilized lipases existing within a porous structure are applied in the industrial context. The enzyme molecules are inaccessible to any external interface and hence cannot undergo interfacial activation. Immobilizing the enzyme by adsorption onto hydrophobic supports could serve as a simple alternative to circumvent this problem (3). The hydrophobic supports resemble the surface of the enzyme's natural substrate and hence the enzyme binds to them with high affinity. When the procedure is carried out under conditions of low ionic strength, other water soluble proteins are excluded and the process becomes highly selective for the lipases (4). Hydrophobic areas surrounding the active site and located in the internal face of the lid are involved in this adsorption process. This fixes the enzyme in its open conformation and enables good enzyme activity 
regardless of whether the interface required for its activation is present or not.

Lipase immobilized in this manner could be productively exploited for a wide range of applications, and in the present study, it was used for biodiesel production. Alternatives to fossil fuels, biodiesel derived from vegetable oils is gaining prominence. Replacing the chemical catalysts used in biodiesel production with biocatalysts shall further enhance the environmental acceptability of the process and lipases could play a prominent role in this sector. They catalyse the transesterification of triacylglycerol with short chain alcohols and immobilization of the enzyme is especially advantageous as it enhances stability and permits reusability (5). The enzyme used in this study was the purified lipase derived from Bacillus sp. that was previously isolated in our lab from oil contaminated site.

\section{Materials and Methods}

\subsection{Materials}

$p$-Nitrophenyl palmitate and Diaion HP-20 beads were purchased from Sigma-Aldrich, USA. All other chemicals used were of analytical grade and obtained from standard sources in India.

\subsection{Source of Lipase}

This study was performed with the bacterial strain Bacillus sp. PS35 (Accession No. KJ020927) that was previously isolated in our lab from soil sample exposed to poultry slaughterhouse effluent. Its genomic DNA library was constructed in pUC18 and E. coli DH5 $\alpha$ cells were transformed with the ligated products. Clone 4 which showed good lipase activity was sequenced. The deduced nucleotide sequence of the lipase gene was submitted to Genbank (Accession No. KM225297). The recombinant enzyme (designated as $C$-4 lipase) was purified 19.41-fold from $E$. coli culture and its molecular weight was determined to be around $29 \mathrm{kDa}$.

\subsection{Lipase Immobilization}

$C-4$ lipase was immobilized by cross-linking of the enzyme molecules with gluteraldehyde and adsorption onto Diaion HP-20 beads, comprising of a hydrophobic Sty-Dvb resin (6). The hydrophobicity of the resin can impede penetration of water into its pores. Hence, the beads $(1 \mathrm{~g})$ were suspended in $100 \mu \mathrm{L}$ of the organic solvent acetonitrile for $1 \mathrm{~h}$, followed by addition of an equal amount of water and left for another $1 \mathrm{~h}$, both processes being carried out under mild agitation of 30 $\mathrm{rpm}$. The beads were washed with 4 volumes of water.

One half of the washed beads were treated with $2.5 \%$ gluteraldehyde for $1 \mathrm{~h}$. They were washed 3 times with distilled water to remove residual gluteraldehyde. $5 \mu \mathrm{L}$ of purified $C-4$ lipase was added to the beads, with and without gluteraldehyde treatment, and left on shaker $(60 \mathrm{rpm})$ for $90 \mathrm{~min}$. The samples were centrifuged at $1000 \times \mathrm{g}$ for $5 \mathrm{~min}$. The supernatant was tested for unbound protein and enzyme activity. HP-20 beads were washed thrice in $50 \mathrm{mM}$ phosphate buffer, $\mathrm{pH} 7$ and used for the experiments. The immobilized enzymes were referred to as Sty-Dvb (non-crosslinked) and Sty-Dvb-Glu (cross-linked).

Lipase activity was quantified using spectrophotometric assay with $p$-NPP as the substrate (7). The absorbance was measured at $410 \mathrm{~nm}$, against an enzyme-free blank. Molar extinction coefficient of $0.0146 \mu \mathrm{M}^{-1} \mathrm{~cm}^{-1}$ was used. One unit of lipase activity was defined as $\mu \mathrm{M}$ of $\mathrm{p}$-Nitrophenol released per minute under the assay conditions. All activity assays were performed in triplicate and the values given represent the mean. Protein content was measured using Folin's phenol reagent (8).

\subsection{Characterization of the Immobilized Lipase}

The efficiency of the immobilization process was evaluated by determining the enzyme activity, specific activity, protein loading, and activity yield.

\subsection{Stability Studies}

After incubating the lipase preparations under various conditions for $1 \mathrm{~h}$, activity assays were performed using phosphate buffer $\mathrm{pH} \mathrm{7,} \mathrm{under} \mathrm{standard} \mathrm{condi-}$ tions of $30^{\circ} \mathrm{C}$ incubation temperature and $15 \mathrm{~min}$ incubation time. The free enzyme was used as such for the assay and the immobilized lipase was separated by filtration, air dried and then used. The results were expressed as relative activities, taking the activity of the unincubated enzyme sample to be $100 \%$

\section{6. $p H$ and Temperature Stability}

For testing the $\mathrm{pH}$ stability, the enzymes were incubated in buffers of $\mathrm{pH}$ 3.0-10.0. Citrate, phosphate and Tris$\mathrm{HCl}$ buffers $(100 \mathrm{mM})$ were used for the acidic, neutral and alkaline ranges, respectively. The thermal stability was determined through activity assays performed after incubating the enzyme preparations at $30-80^{\circ} \mathrm{C}$.

\subsection{Organic Solvent Stability}

The organic solvent stability of the free and immobilized forms of the enzyme was assessed by incubat- 
ing them in $10 \%(\mathrm{v} / \mathrm{v})$ ethanol, methanol, isopropanol, $\mathrm{n}$-hexane, toluene, and chloroform followed by checking of the residual activity.

\subsection{Storage Stability and Reusability}

The stability of the free and immobilized enzymes stored in phosphate buffer $\mathrm{pH} 7.0$, at $4^{\circ} \mathrm{C}$ was tested over a month's period and any activity loss occurring during this period was documented by taking the freshly obtained enzyme as control. The reusability of the immobilized enzyme was evaluated by repeatedly using the enzyme for $p$-NPP hydrolysis. After each use, the enzyme beads were washed thrice in phosphate buffer, $\mathrm{pH}$ 7.0.

\subsection{Kinetic Constants}

Initial reaction velocity was measured by varying the substrate concentration at constant enzyme concentration and used for determining the MichaelisMenten kinetics. The concentration of the $p$-NPP substrate was varied from 3.0 to $24.0 \mathrm{mM}$. The slope and $\mathrm{y}$-axis intercept on the Lineweaver-Burk plot of 1/S versus $1 / \mathrm{V}$ were used for calculating the $K_{m}$ and $\mathrm{V}_{\max }$ values, respectively.

\subsection{Biodiesel Production Using the Immobilized C-4 Lipase}

\subsubsection{Methanolysis}

Palm oil was used for methanolysis and the reaction was performed in screw cap bottles. The immobilized enzyme was reacted with methanol and oil that were added in a molar ratio of $4: 1$. The reaction mixture consisted of 100 beads of the immobilized enzyme, palm oil $9.63 \mathrm{~g}$, methanol $0.37 \mathrm{~g}$, and distilled water $0.5 \mathrm{~g}$. It was incubated for $96 \mathrm{~h}$ at a temperature of $40^{\circ} \mathrm{C}$, in an incubator-shaker set at $90 \mathrm{rpm}$.

\subsection{Optimization of Process Parameters}

The reaction conditions were modified in order to assess their effects on methanolysis efficiency. Firstly, the methanol additions were performed in a phased manner (single, two and three step additions), occurring at 0,36 and $72 \mathrm{~h}$ of reaction, amounting to a total of 4 molar equivalents of palm oil. This measure was aimed at avoiding enzyme inactivation by the high methanol content. Subsequently, the molar ratio of methanol and oil was varied (1:4, 1:5 and 1:6) and the ratio for optimal FAME synthesis was determined. The effect of water activity on the reaction was also studied by varying the water content from 0 to $20 \%$. The incubation temperature of the reaction mixture was later varied $\left(40^{\circ} \mathrm{C}, 45^{\circ} \mathrm{C}\right.$ and $\left.50^{\circ} \mathrm{C}\right)$ and its effect on FAME production was assessed.

\subsection{Gas Chromatography Analysis}

Samples were withdrawn from the reaction mixture at regular time intervals and centrifuged at $12,000 \times \mathrm{g}$ for $5 \mathrm{~min}$. The upper oil layer was withdrawn and analysed using a gas chromatographic system (Shimadzu, Japan). Methyl ester (ME) content and glycerides content (mono, di and triglycerides) were estimated. A DB-5 capillary column $(0.25 \mathrm{~mm} \times 15 \mathrm{~m}$, Agilent, India) of fused silica type and flame ionization detector (FID) (split/splitless injection system with auto-sampler) were used. Hydrogen was used as carrier gas (average linear velocity $30 \mu \mathrm{L} / \mathrm{min}$ ). The injector and detector temperatures were maintained at 245 and $320^{\circ} \mathrm{C}$, respectively. The column temperature was initially set at $150^{\circ} \mathrm{C}$ for $1 \mathrm{~min}$, then increased to $300^{\circ} \mathrm{C}$ at the rate of $10^{\circ} \mathrm{C}$ per min and maintained at that temperature for $10 \mathrm{~min}$. The result for the FAME content was expressed as a mass fraction in percent using methyl heptadecanoate $(\mathrm{C} 17)$ as the internal standard.

\section{Results}

\subsection{Lipase immobilization and Characterization}

The Sty-Dvb-Glu lipase exhibited an activity of $15.48 \mathrm{U} / \mathrm{g}$ of support and a specific activity of 1.09 $\mathrm{U} / \mathrm{mg}$ of protein. Higher protein loading of $74.12 \%$ onto the resin was also achieved after enzyme crosslinking, as against a loading rate of $56.32 \%$ without cross-linking. Cross-linking also resulted in a better activity yield of $79.48 \%$.

\subsection{Stability Studies}

Maximum enzyme stability was observed in the $\mathrm{pH}$ range of 6-8. Incubation in $\mathrm{pH} 10$ buffer resulted in $49 \%$ activity loss of the free enzyme. However, the polymer-adsorbed enzyme suffered a substantially lower activity loss of $28 \%$, which further came down to $24 \%$ upon cross-linking (Figure 1A). In the case of temperature stability, while the free lipase showed good stability ( $87 \%$ relative activity) in the range of 30 $-50^{\circ} \mathrm{C}$, the immobilized enzyme exhibited good activity retention upon exposure to an elevated temperature of $60^{\circ} \mathrm{C}$. Moreover, stability at a much higher temperature of $80^{\circ} \mathrm{C}$ had nearly doubled for the cross-linked and adsorbed enzyme (Figure 1B). Similarly, while the free enzyme was less stable in the presence of organic 
A

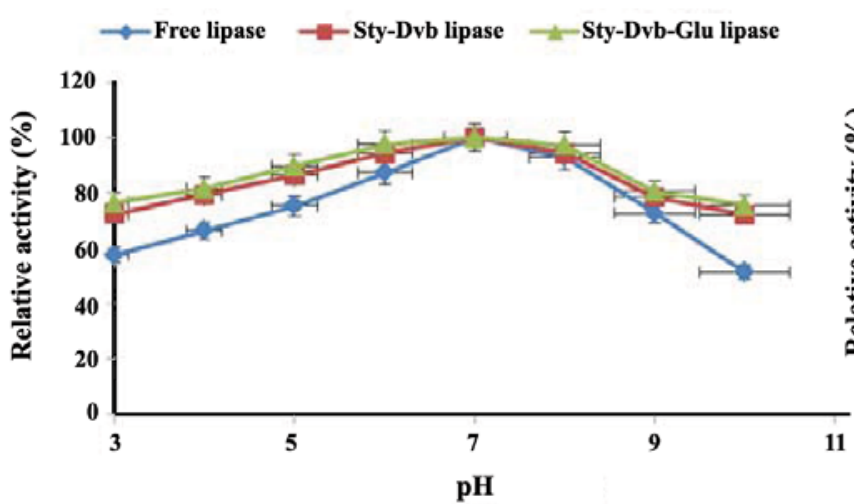

B

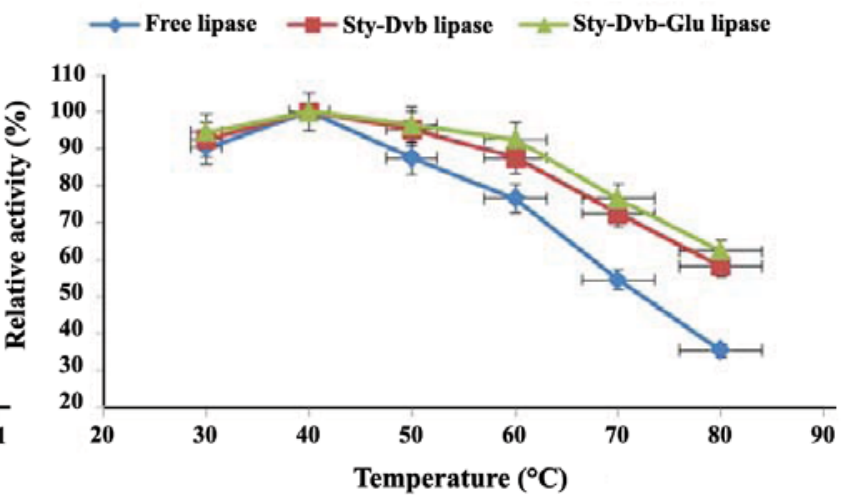

Figure 1. A: pH and B: temperature stabilities of the free and immobilized lipase preparations. The buffer systems used were $100 \mathrm{mM}$ citrate, phosphate and Tris-HCl buffers for the acidic, neutral and alkaline ranges, respectively (A). All activity assays were performed using phosphate buffer $\mathrm{pH} \mathrm{7,} \mathrm{under} \mathrm{standard} \mathrm{conditions} \mathrm{of} 30^{\circ} \mathrm{C}$ and 15 min incubation. The activity of the unincubated enzyme sample was taken to be $100 \%$

solvents such as $n$-hexane and toluene, the stability increased remarkably after adsorption onto the hydrophobic resin. Gluteraldehyde cross-linking led to a marginal increase in this adsorption conferred stability. A minimum of $20 \%$ increase in relative activity was observed as a result of immobilization. Specifically, the relative activity in the presence of methanol was shifted from $53 \%$ to $81 \%$, after the immobilization, thereby favoring the enzyme's application in FAME synthesis (Figure 2). The storage stability of the free enzyme was poor, with it retaining only $18.36 \%$ of its initial activity after a month's storage in $\mathrm{pH} 7$ phosphate buffer. However, adsorption of the enzyme molecules onto the Sty-Dvb resin increased their stability dramatically, with $50.23 \%$ activity retention after a similar period of time. This was further augmented to $75.97 \%$ upon cross-linking with gluteraldehyde (Figure 3A). The immobilized

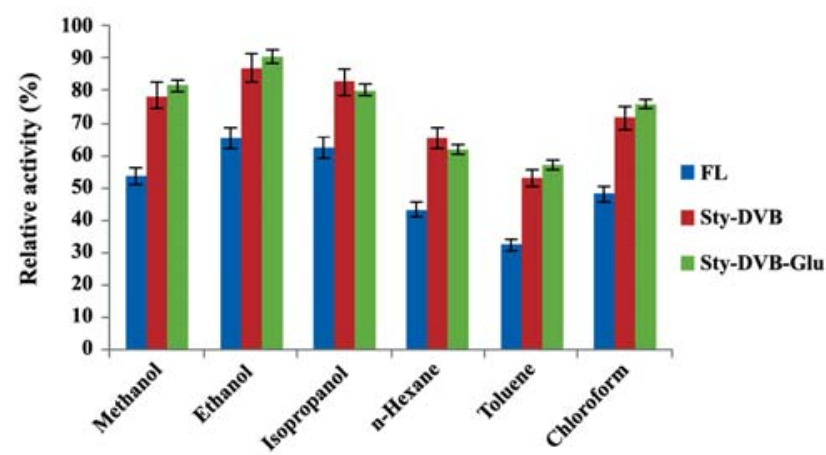

Figure 2. Organic solvent stability of free and immobilized lipase preparations. The organic solvents were tested at $10 \%$ $(\mathrm{v} / \mathrm{v})$ concentration. The activity of the unincubated enzyme sample was taken to be $100 \%$ enzyme molecules also showed good reusability. The cross-linked lipase retained $77.5 \%$ of its original activity after 20 uses, while the non-cross-linked enzyme was able to retain only $60.03 \%$ of its activity after the same number of repetitive uses ( Figure 3B).

\subsection{Kinetic Constants}

The $\mathrm{K}_{\mathrm{m}}$ values of the free and immobilized (Sty-DvbGlu) lipase preparations were calculated to be $6.24 \pm 0.14$ and $6.91 \pm 0.13 \mu \mathrm{M}$, respectively. Their $\mathrm{V}_{\max }$ values were determined to be $16.87 \pm 0.34$ and $15.34 \pm 0.16 \mu \mathrm{M} / \mathrm{min}$, respectively from the Lineweaver-Burk plot (not shown).

\subsection{Biodiesel Production Using Immobilized C-4 Lipase}

Preliminary trials on palm oil methanolysis under arbitrarily fixed conditions of single step methanol addition in a molar ratio of $4: 1$ and incubation temperature of $40^{\circ} \mathrm{C}$ resulted in FAME yield of $62.53 \%$. When single factor optimization of process parameters was performed, the yield was considerably improved. Methanol and oil molar ratio of 5:1, three step methanol additions, and an incubation temperature of $50^{\circ} \mathrm{C}$ were established to be the ideal conditions conducive for the transesterification reaction. A maximum of $97 \%$ conversion was observed under these optimal conditions. The methyl ester, glycerides (mono, di, and triglycerides), free glycerol and fatty acid contents of the biodiesel are listed in (Table 1).

While single step methanol addition resulted in only a low ME yield of $56.47 \%$, it was amply improved in two-step addition, yielding $73.12 \%$ esters. 
$\mathbf{A}$

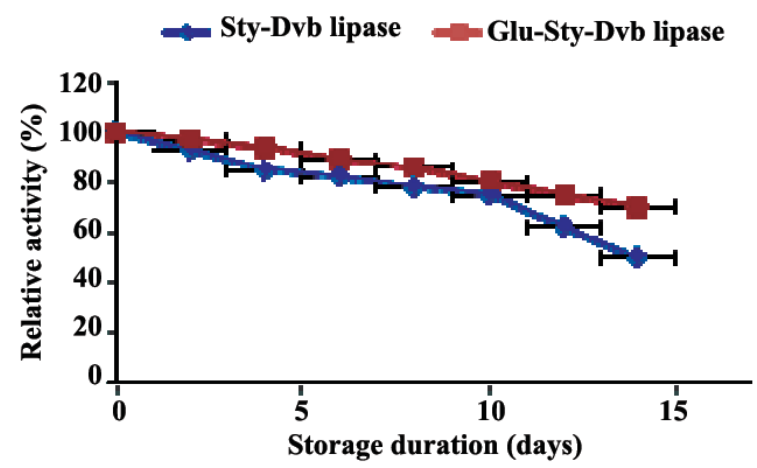

B

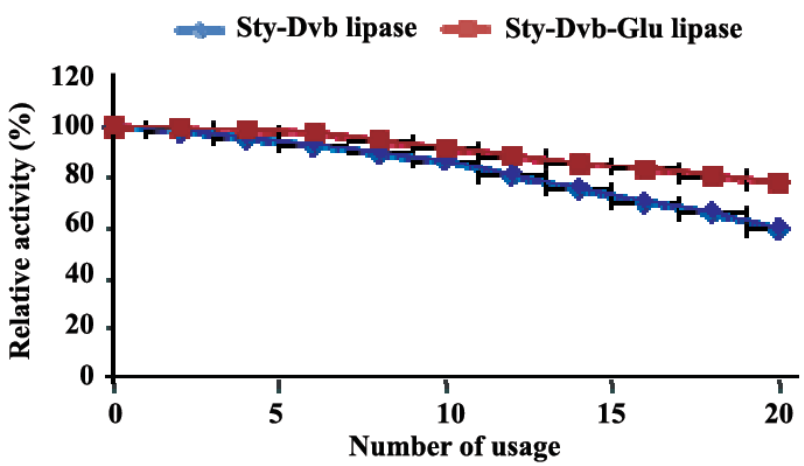

Figure 3. A: Storage stability and B: reusability of the free and immobilized lipase preparations. During the stability studies, the enzyme was stored in phosphate buffer $\mathrm{pH} 7.0$, at $4^{\circ} \mathrm{C}(\mathrm{A})$. Reusability was tested by repeatedly using the enzyme for $\mathrm{p}$-NPP hydrolysis, washing the beads in $\mathrm{pH} 7$ phosphate buffer after each use (B). The activity of the unincubated enzyme sample was taken to be $100 \%$

This was further enhanced to $89.32 \%$ in three-step addition (Figure 4A). However, a further increase in water content to $20 \%$ was not helpful for the reaction and the ester yield fell down to $48.53 \%$. Incubation temperature also impacted the lipase catalysed transesterification reaction tremendously. FAME formation at $40^{\circ} \mathrm{C}$ was $73.97 \%$, which was increased to $88.74 \%$ at $45^{\circ} \mathrm{C}$, and further to $96.12 \%$ at $50^{\circ} \mathrm{C}$ (Figure $4 \mathrm{~B}$ ). When the impact of methanol and oil molar ratio was investigated, highest FAME accumulation of 97.01\% was observed at a ratio of 5:1. A lower yield of 78.63\% was noticed at a molar ratio of $4: 1$. When the ratio was increased further to $6: 1$, the yield was comparable up to $36 \mathrm{~h}$, after which the reaction slowed down and the final yield after $96 \mathrm{~h}$ incubation amounted to only $89 \%$ (Figure 4C). Lowest ME yield of 37.23\% was obtained in the total absence of water. Increasing the water content to $10 \%$ hiked the ester yield to a maximum of $96.87 \%$ (Figure 4D).

\section{Discussion}

\subsection{Immobilization Efficiency}

Immobilized lipase preparations, especially the cross-linked ones, showed good performance in terms of enzyme activity, specific activity, protein loading, as well as activity yield. The high activity yield obtained means that this method of immobilization is suitable for the enzyme's application in heterogenousbiocatalysis. Gluteraldehyde cross-linking has also been shown to increase the efficiency of Burkholderia cepacia lipase entrapped in alginate and k-carrageenan hybrid matrix (9)

\subsection{Stability Studies}

Culture medium $\mathrm{pH}$ can have a profound impact on the charged groups present on the enzyme surface, which in turn may influence its structure and function. If the charges on the amino acid residues in the active site are altered, substrate binding may be considerably affected. Thus, $\mathrm{H}^{+}$ions and $\mathrm{OH}^{-}$ions can modify the enzyme's activity as a result of changes in the three dimensional structure of the enzyme, that especially occur at the active site. The immobilized enzymes were stable in a broader $\mathrm{pH}$ range, which enhance their industrial applicability. Adsorption onto the support could have minimized the changes in stereo configurations occurring in the immediate vicinity of the active site and contributed to enzyme stability. Better $\mathrm{pH}$ stability of immobilized enzymes has been established in

Table 1. Glycerides, glycerol and free fatty acid contents of the biodiesel

\begin{tabular}{lccccc}
\hline $\begin{array}{l}\text { Methyl esters \% } \\
(w / w)\end{array}$ & $\begin{array}{c}\text { Triglycerides } \% \\
(w / w)\end{array}$ & $\begin{array}{c}\text { Diglycerides } \% \\
(w / w)\end{array}$ & $\begin{array}{c}\text { Monoglyecerides \% } \\
(w / w)\end{array}$ & $\begin{array}{c}\text { Free glycerol \% } \\
(w / w)\end{array}$ & $\begin{array}{c}\text { Free fatty acids } \% \\
(w / w)\end{array}$ \\
\hline $97.28 \pm 1.591(96.5)$ & $0.16 \pm 0.008(0.2)$ & $0.12 \pm 0.005(0.2)$ & $0.49 \pm 0.022(0.7)$ & $0.02 \pm 0.006(0.02)$ & $0.32 \pm 0.024(0.5)$ \\
\hline
\end{tabular}

EN 14214 limits (lower limit for methyl esters and upper limit for other parameters) are given within brackets 
A

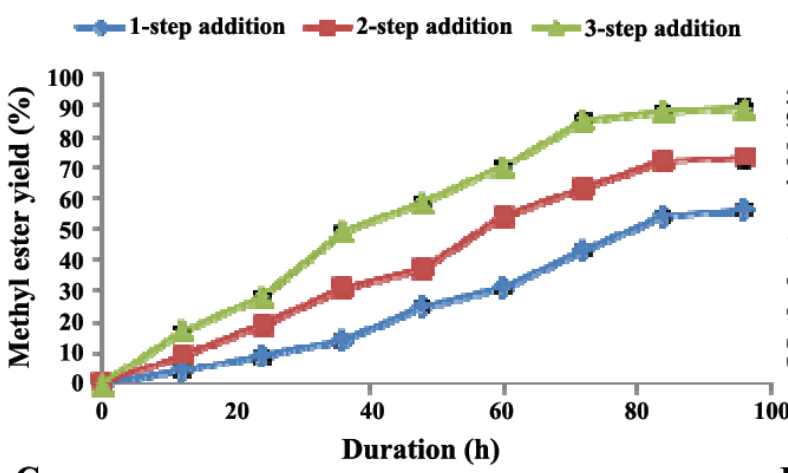

C

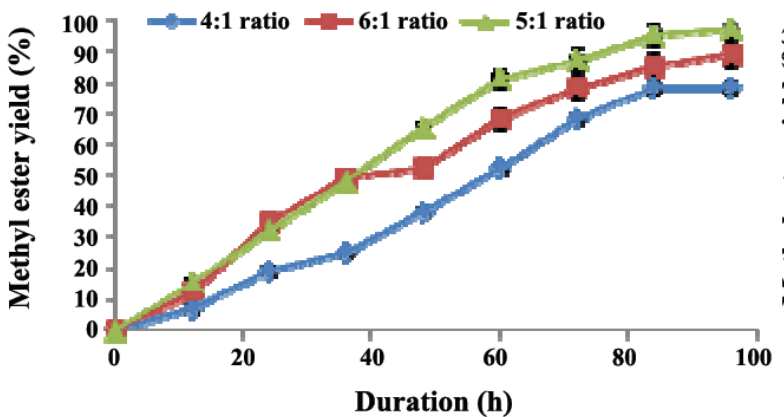

B

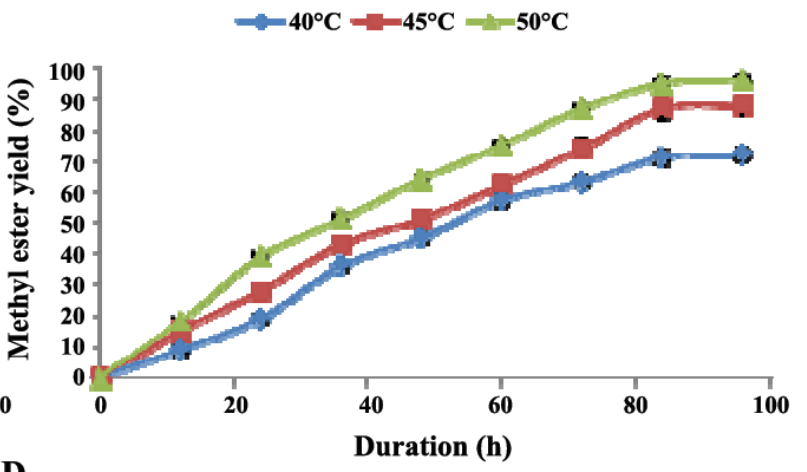

D

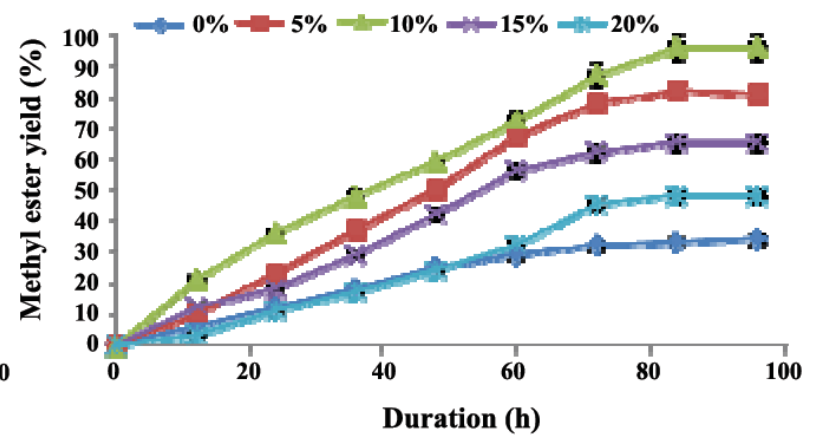

Figure 4. Effects of different process parameters on FAME yield. A: stepwise methanol addition B:temperature C: methanol and oil molar ratio D: water activity

several studies. For instance, Rhizopus oryzae lipase immobilized on silica aerogels by adsorption had retained $95 \%$ of its activity within a $\mathrm{pH}$ range of 5-9, while the soluble enzyme had lost $60 \%$ of its activity at $\mathrm{pH} 5$ and $30 \%$ of its activity at $\mathrm{pH} 9$ (10).

Thermal stability is another important requirement which enables the enzyme to function as a biocatalyst at elevated temperatures that may be required for certain reactions to proceed, such as the synthesis of FAME. Immobilized enzymes are known to have better thermal stability than free enzymes. This has been corroborated by results from the present investigation, as well as certain earlier studies. Upon incubation for $24 \mathrm{~h}$ at $50^{\circ} \mathrm{C}$, free lipase from Pseudomonas gessardii had retained an activity of $52 \%$ while its immobilized counterpart had displayed a residual activity of $79 \%$ (11). Organic solvent stability of the lipase is of paramount importance, if it is to be applied for catalysing esterification, transesterification and interesterification reactions in water restricted environments. Although the free enzyme was less stable in the presence of organic solvents such as n-hexane and toluene, the stability increased remarkably after adsorption onto the hydrophobic resin. Such observations have also been reported elsewhere in literature (12). Accentuated ther- mostability and organic solvent stability conferred on the lipase by immobilization were particularly handy in catalysing the transesterification reaction.

Enhancement of storage stability is often a prime objective to be met by immobilized enzymes, so as to make them more attractive for commercial applications (13). Immobilization conditions determine enzyme stability, as it depends on the interactions between the enzyme and the support matrix (14). Reusability is another desired attribute for immobilized enzymes, making the process more economical for the industry that applies them (15). Immobilized $C$ 4 lipase exhibited these desirable traits, which enhanced its prospects of being applied in biodiesel production. Earlier, Pseudomonas gessardii lipase immobilized on mesoporous activated carbon had retained $54 \%$ of its activity after 30 days of storage (11). Thermomyces lanuginosus and Pseudomonas fluorescens lipases immobilized on epoxy-chitosan/alginate support had retained $95 \%$ of their activities after the fifth reuse in butyl oleate synthesis (16). Lipases immobilized on regenerated cellulose and glass fiber membranes have been shown to retain 16 and $41 \%$ of their original activities, respectively, after 10 repetitive uses (17).

Enzyme leakage is a pressing problem that often 
undermines the performance of enzymes that are immobilized by physical adsorption or entrapment. This has been attributed to the larger pore size of the resin in comparison with the size of the enzyme molecules. When the enzyme molecules are cross-linked with bifunctional reagents such as glutaraldehyde, their increased size minimizes leakage (18). Glutaraldehyde is present in the solution in different forms that are in equilibrium with each other at a specific $\mathrm{pH}$. Even though different models have been put forth to explain the chemical basis of cross-linking, the mechanism has not been entirely elucidated (19).

\subsection{Kinetic Constants}

Immobilization may alter the enzyme kinetic constants favorably or otherwise. For instance, an increase in $\mathrm{K}_{\mathrm{m}}$ value for the immobilized enzyme has been reported, which translates into a decreased affinity for the substrate. This may be due to the support posing steric hindrance and blocking access to the active site or a loss of the much needed substrate flexibility. Problems associated with diffusional limitations may also be encountered, thereby affecting the reaction rate (20). The $\mathrm{K}_{\mathrm{m}}$ value for Burkholderia lipase immobilized on celite carrier has been reported to be much higher than that for free lipase, suggesting diffusion resistance. Also, the $\mathrm{V}_{\max }$ was lesser, probably due to blocking of the active site (21). However, in case of the $C-4$ lipase the kinetic constants of the immobilized enzyme were not significantly altered.

\subsection{Biodiesel Production Using the Immobilized Lipase}

The chemical composition of the biodiesel was in agreement with the EN 14214 standards. The incubation time and methyl ester yield obtained were comparable to other reports. A period of 72-96 h has generally been reported for maximum methyl ester formation (22). Bulk addition of large amounts of organic solvent had inhibitory effects on the enzyme, while adding the same amount in small increments was well tolerated by the enzyme. Methanol addition pattern and its effect on ester content have been studied extensively and in one such study involving packed bed reactor, 44.5 molar equivalents of methanol had been added totally and the optimal amount of methanol per pass was found to be dependent on the reaction stage (23). Methanol and oil molar ratio also influenced the FAME yield from the process. A whole cell biocatalyst Rhodotorula mucilagenosa yielded $83.29 \%$ FAME with a 6:1 molar ratio of methanol and palm oil (24).
Water activity in the reaction mixture was another factor that impacted the process outcome significantly. Other researchers have also reported $10 \%$ to be the optimum water content for palm oil transesterification (24). Incubation temperature was also observed to play a key role in the reaction. In previous studies, application of Aspergillus oryzae whole cell biocatalyst expressing Geobacillus thermocatanulatus lipase (rBTL) for palm oil methanolysis had resulted in near $100 \%$ FAME formation at $40-50^{\circ} \mathrm{C}(25)$. Hence, this study has facilitated the optimization of process parameters and ascertained the conditions that are conducive for maximizing the ME yield from palm oil.

To sum up, this work has enabled the immobilization of lipase from Bacillus sp. PS35 on a hydrophobic support that is beneficial for its catalytic action. This might be due to the enzyme being fixed in a perpetually open conformation, obviating the necessity for interfacial activation. The styrene-divinyl benzene resin has shown good immobilization efficiency and the immobilized enzyme has displayed superior characteristics in terms of $\mathrm{pH}$, temperature, organic solvent and storage stabilities, with prior gluteraldehyde crosslinking further enhancing the stability of the adsorbed enzyme molecules. The enzyme has also been successfully applied in an emerging area of green chemistry, namely, enzymatic biodiesel production. With biodiesel being widely acclaimed as an environmentally sound replacement to the non-renewable and much polluting fossil fuels, the enzymatic route to its synthesis needs to be thoroughly explored. Ability to perform under high temperatures and in the presence of organic solvents are much needed criteria for such enzymes and $C-4$ lipase has fulfilled these criteria, more so upon immobilization onto an appropriate support. It could hence serve as a suitable biocatalyst for the enzymatic biodiesel production.

\section{Acknowledgements}

The authors are thankful to the management of Kumaraguru College of Technology, Coimbatore, India, for providing the laboratory facilities to carry out this work.

\section{Conflict of interest}

The authors have no substantial financial or commercial conflicts of interest with the current work or its publication.

\section{References}

1. Schmid RD, Verger R. Lipases: interfacial enzymes with attrac- 
tive applications. Angew Chem Int Ed. 1998;37:1608-1633. DOI: $0.1002 /($ SICI)1521-3773(19980703)37:12<1608::AIDANIE1608>3.0.CO;2-V

2. Uppenberg J, Hanse M, Patkar S, Jones TA. The sequence, crystal structure determination and refinement of two crystal forms of lipase B from Candida Antarctica. Structure 1994;2:293-308. DOI: 10.1016/S0969-2126(00)00031-9

3. Palomo JM, Munoz G, Fernandez-Lorente G, Mateo C, Fernandez-Lafuente C, Guisan JM. Interfacial adsorption of lipases on very hydrophobic support (Octadecyl-Sepabeads): Immobilization, hyperactivation and stabilization of the open form of lipases. J Mol Catal B Enzym. 2002;11:279-286. DOI: 10.1016/S1381-1177(02)00178-9

4. Miled N, Beisson F, Caro J, Caro A, Arondel V, Verger R. Interfacial catalysis of Lipases. J Mol Catal B Enzym. 2001;11:165-171. DOI: 10.1016/S1381-1177(00)00041-2

5. Tran DT, Yeh KL, Chen CL, Chang JS. Enzymatic transesterification of microalgal oil from Chlorella vulgaris ESP-31 for biodiesel synthesis using immobilized Burkholderialipase. Bioresour Technol. 2012;108:119-127. DOI: 10.1016/j.bio rtech.2011.12.145

6. Dizge N, Keskinler B, Tanriseven A. Biodiesel production from canola oil by using lipase immobilized onto hydrophobic microporous styrene-divinylbenzenecopolymer. Biochem Eng J. 2009;44:220-225. DOI: 10.1016/j.bej.2008.12.008

7. Winkler UK, Stuckmann M. Glycogen, hyaluronate and some other polysaccharides greatly enhance the formation of exolipase by Serratiamarcescens. J Bacteriol. 1979;138:663-670.

8. Lowry $\mathrm{OH}$, Rosebrough NJ, Farr AL, Randall RJ. Protein measurement with the Folin phenol reagent. J Biol Chem. 1951;193(1):265-275.

9. Abdulla R, Ravindra P. Characterization of cross linked Burkholderiacepacia lipase in alginate and k-carrageenan hybrid matrix. J Taiwan Inst Chem Eng. 2013;44:545-551. DOI: $10.1016 /$ j.jtice.2013.01.003

10. Ramani K, Boopathy R, Vidya C, Kennedy L, Velan M, Sekaran G. Immobilization of Pseudomonas gessardii acidic lipase derived from beef tallow onto mesoporous activated carbon and its application on hydrolysis of olive oil. Process Biochem. 2010;45:986-992. DOI: 10.1016/j.procbio.2010.03. 005

11. Azevedo AM, Prazetes DMF, Cabral JMS, Fonseca LP. Stability of free and immobilized peroxidase in aqueousorganic solvents mixtures. $J$ Mol Catal B Enzym. 2001;15:147-153.

12. Tang S, Jiang L, Zou B, Yang J, Huang H. Immobilization of Burkholderia cepacia lipase on functionalized ionic liquids modified mesoporous silica SBA-15. Process Biochem. 2012;47:2291-2299. DOI: 10.1016/j.procbio.2012.09.007

13. Hung TC, Giridhar R, Chiou SH, Wu WT. Binary immobilization of Candida rugosalipase on chitosan. J Mol Catal B Enzym. 2003;26:69-78. DOI: 10.1016/S1381-1177(03)00167-X

14. Kharrat N, Ali YB, Marzouk S, Gargouri YT, Karra-Chaabouni M. Immobilization of Rhizopusoryzae lipase on silica aerogels by adsorption: Comparison with the free enzyme. Process Biochem. 2011;46:1083-1089. DOI: 10.1016/j.procbio.2011.01. 029

15. Mendes A, Castro H, Andrade G, Tardioli P, Giordano R. Preparation and application of epoxy-chitosan/alginate support in the immobilization of microbial lipases by covalent attachment. React Funct Polym. 2013;73:160-167. DOI: 10. 1016/j.reactfunctpolym.2012.08.023

16. Chen GJ, Kuo CH, Chen CI, Yu CC, Shieh CJ, Liu YC. Effect of membranes with various hydrophobic/hydrophilic properties on lipase immobilized activity and stability. J Biosci Bioeng. 2012;113(2):166-172. DOI: 10.1016/j.jbiosc.2011. 09.023

17. Yadav GD, Jadhav SR. Synthesis of reusable lipases by immobilization on hexagonal mesoporous silica and encapsulation in calcium alginate. Micropore Mesopore Mater. 2005;86: 215-222. DOI: 10.1016/j.micromeso.2005.07.018

18. Mignieault I, Dartiguenave C, Bertrand MJ, Waldron KC. Glutaraldehyde: behaviour in aqueous solution, reaction with proteins, and application to enzyme crosslinking. BioTechniques 2004;37:790-802.

19. Kara F, Demirel G, Tumturk H. Immobilization of urease by using chitosan-alginate and poly (acrylamide-co-acrylamide) k-carrageenan supports. Bioprocess Biosyst Eng. 2006;29: 207-211. DOI: 10.1007/s00449-006-0073-0

20. Liu CH, Lin YH, Chen CY, Chang JS. Characterization of Burkholderia lipase immobilized on celite carriers. J Taiwan Inst Chem Eng. 2009;40:359-363.

21. Bajaj A, Lohan P, Jha PN, Mehrotra R. Biodiesel production through lipase catalysed transesterification: an overview. $J$ Mol Catal B Enzym. 2010;62:9-14. DOI: 10.1016/j.molcatb. 2009.09.018

22. Yoshida A, Hama S, Tamadani N, Fukuda H, Kondo A. Improved performance of a packed-bed reactor for biodiesel production through whole-cell biocatalysis employing a highlipase-expression system. Biochem Eng J. 2012;3:76-80. DOI: 10.1016/j.bej.2011.11.003

23. Srimhan P, Kongnum K, Taweerodjanakarn S, Hongpattarakere T. Selection of lipase producing yeasts for methanol-tolerant biocatalyst as whole cell application for palm-oil transesterification. Enzym Microb Tech. 2011;48:293-298. DOI: 10.1016/j. enzmictec.2010.12.004

24. Adachi D, Koh F, Hama H, Ogino C, Kondo A. A robust wholecell biocatalyst that introduces a thermo- and solvent-tolerant lipase into Aspergillus oryzae cells: Characterization and application to enzymatic biodiesel production. Enzym Microb Technol. 2013;52:331-335. DOI: 10.1016/j.enzmictec.2013.03. 005 